Original Research Paper

\title{
Morphological Variations and New Species Description of Genus Rousettus Bat from Gunung Duasudara Sanctuary, North Sulawesi, Indonesia
}

\author{
${ }^{1,2}$ Hanry Jefry Lengkong, ${ }^{3}$ Endang Arisoesilaningsih, ${ }^{3}$ Luchman Hakim and ${ }^{4}$ Sudarto \\ ${ }^{I}$ Doctoral Student of Biology Department, \\ Faculty of Mathematics and Natural Sciences, Brawijaya University, Malang, Indonesia \\ ${ }^{2}$ Faculty of Mathematics and Natural Sciences, Sam Ratulangi University, Manado, North Sulawesi, Indonesia \\ ${ }^{3}$ Department of Biology, Faculty of Mathematics and Natural Sciences, Brawijaya University, Malang, Indonesia \\ ${ }^{4}$ Faculty of Agriculture, Brawijaya University, Malang, Indonesia
}

Article history

Received: 24-11-2015

Revised: $19-02-2016$

Accepted: 26-03-2016

Corresponding Author: Hanry Jefry Lengkong Faculty of Mathematics and Natural Sciences, Sam

Ratulangi University, Manado,

North Sulawesi, Indonesia

Email: hanry_lengkong@yahoo.co.id

\begin{abstract}
Bats belongs to Pteropodidae Family that spreaded evenly in Indonesia. Genus Rousettus have their morphological variances among its own species based on characteristics on each species. Among them there is fruit-feeding bats of from genus Rousettus (Chiroptera: Pteropodidae) that have many variances of morphology among its own species. This study was aimed to identify the morphological variations and its sex type influence of genus Rousettus bats from Gunung Duasudara Sanctuary, North Sulawesi. The locations were consisted 7 types of major vegetations at altitude range from 0 to $1351 \mathrm{~m}$ above sea level (asl). All habitat types were observed using Mist-net method at 1 and $3 \mathrm{~m}$ above the ground. There were found 452 individuals, including $R$. amplexicaudatus (224), R. celebensis (219) and R. tangkokoensis n. sp. (9). Nine individuals of Rousettus tangkokoensis n. sp. were newly found in lowland forest and coastal forest. These newly-found species were different from other Rousettus. There was discovered that sex type had influenced the skull and external body characters on $R$. amplexicaudatus, R. tangkokoensis n. sp. R. celebensis. However, most of other characters were statistically not-significant that indicated there was not any sexual dimorphism. According to the Discriminant Function Analysis (DFA), these morphological groups possess different specification. Therefore, the three species of genus Rousettus have statistically variation of skull and external body characters one to another.
\end{abstract}

Keywords: North Sulawesi, Gunung Duasudara Sanctuary, Rousettus

\section{Introduction}

Indonesia contains many species of nocturnal animals, especially bats. Bats belong to Pteropodidae Family that spreaded evenly in Indonesia. There are many research reports about bats spreads along Sulawesi Island. Bergmans and Rozendaal (1988) reported that in Sangihe islands and Selayar, Sulawesi, there were 21 species of Pteropodidae Family. On the other hand, according to Suyanto (2001) and Suyanto et al. (2002), there were 25 species of Pteropodidae in Sulawesi.

Lee et al. (2001) found 9 species of bats in 6 natural vegetations in Gunung Duasudara Sanctuary, Sulawesi, the bat species were found are: Rousettus celebensis, Cynopterus brachyotis, Thoopterus nigrescens, Nyctimene cephalotes, Macroglossus minimus, Megaderma spasma, Pteropus hypomelanus, Rhinolopus sp. and Myotis sp. Furthermore, Lengkong (2009) also reported the total of 9 species presence from 4 vegetations in the same location, they found Boneia bidens and Dobsonia exoleta species that previously unreported. However, Lengkong (2009) did not find 3 species that previously reported by Lee et al. (2001) i.e., M. spasma, P. hypomelanus and Rhinolopus $\mathrm{sp.}$

Among them there is fruit-feeding bats from genus Rousettus (Chiroptera: Pteropodidae) that have many 
variances of morphology among its own species. Genus Rousettus has 9 species which are widely distributed from Indonesia to Southeast Asia, southwest Africa, Madagascar (Corbet and Hill, 1992), Philippine, Papua New Guinea and Solomon (Koopman, 1993). Corbet and Hill (1992) reported that there were 5 species of Rousettus from Indonesia, i.e.: Rousettus (Rousettus) amplexicaudatus (Saint-Hilaire, 1810) which are distributed in Sumatra, Kalimantan, Sulawesi, Mallucas, Java, Bali, Sunda Lesser and S. Burma; R.(R.) celebensis (Andersen, 1907) and Rousettus (Boneia) bidens (Jentink, 1879) in Sulawesi; R.(R.) leschenaultii (Desmarest, 1820) in Java and Pakistan; and R.(R.) spinalatus (Bergmans and Hill, 1980) in Sumatra and Kalimantan.

There are 5 species of Rousettus in Sulawesi, i.e.: Rousettus amplexicaudatus, Rousettus celebensis, Rousettus leschenaultii, Rousettus spinalatus and Rousettus linduensis. Therefore, Sulawesi is an area that possessing high level of endemic fauna and the hot spot of Rousettus species diversity (Suyanto et al., 2002); (Maryanto and Yani, 2003).

Genus Rousettus have small body size compared to other bats genus. They have long snout (Suyanto, 2001; Payne et al., 2000), second finger claw, short tail, wing membrane attached to the body side, except in R. spinalatus (Andersen, 1912; Bergmans and Hill, 1980; Payne et al., 2000; Suyanto, 2001). They have wings attached to the hindfoot base of the first or second foot finger, or around the first or second metatarsal, or between both (Bergmans, 1997).

Genus Rousettus have their morphological variances among its own species based on characteristics on each species. Therefore, this study was aimed to identify the morphological variations in bat species of genus Rousettus in Gunung Duasudara Sanctuary, North Sulawesi.

\section{Materials and Methods}

\section{Study Site}

The study was conducted from November 2013 to August 2014 in Gunung Duasudara Sanctuary, North Sulawesi (Fig. 1). It covered 7 major vegetations at altitude $0-1351 \mathrm{~m}$ above sea level (asl). Samples were obtained using 2 bat nets sized $12 \times 3.6 \mathrm{~m}$, it was set at 1 and $3 \mathrm{~m}$ above the ground. The net setting locations are presented in Fig. 1.

\section{Methods}

The samples were 452 adult bats that had been netted in Gunung Duasudara Sanctuary. Twenty-nine bats were preserved in $70 \%$ alcohol and their skull bones were taken out as specimens (Table 1). The measurements of the specimen's skull, jaw and tooth were done on 18 skull characters and 7 external body characters collected from adult individuals at the accuracy of $0.1 \mathrm{~cm}$ (Fig. 2).

Table 1. ANOVA of skull and external body characters of genus Rousettus based on sex type influnce. The significance levels of F used: $*=\mathrm{p}<0.05, * *=\mathrm{p}<0.01$ dan $* * *=\mathrm{p}<0.001$

\begin{tabular}{|c|c|c|c|}
\hline Characters & R. amplexicaudatus & R. celebensis & R. tangkokoensis n. sp. \\
\hline \multicolumn{4}{|l|}{ a. Skull } \\
\hline GSL & 1.96 & $7.66^{*}$ & 0.35 \\
\hline $\mathrm{ZB}$ & 2.21 & $14.00 * *$ & 1.32 \\
\hline LIW & 2.41 & 0.10 & 2.27 \\
\hline POW & 0.00 & 2.81 & 3.48 \\
\hline $\mathrm{BCW}$ & 0.72 & 0.30 & 0.05 \\
\hline $\mathrm{BL}$ & 0.14 & 0.47 & 1.58 \\
\hline MSF & 1.42 & 0.23 & $14.19 * *$ \\
\hline PL & 0.09 & 0.01 & 0.09 \\
\hline CBL & 0.62 & $7.02 *$ & 0.01 \\
\hline $\mathrm{CCL}$ & 2.63 & 4.44 & 0.01 \\
\hline $\mathrm{C}^{1}-\mathrm{M}^{3}$ & 0.79 & 0.00 & 0.08 \\
\hline $\mathrm{C}^{1}-\mathrm{C}^{1}$ & 2.26 & $8.20 *$ & 1.80 \\
\hline$M^{3}-M^{3}$ & $5.61 *$ & 0.01 & 2.12 \\
\hline DL & 0.41 & 0.03 & 0.25 \\
\hline RAP & 4.13 & $6.94 *$ & 1.12 \\
\hline $\mathrm{C}_{1}-\mathrm{M}_{3}$ & 0.02 & 1.83 & 1.70 \\
\hline $\mathrm{C}_{1}-\mathrm{C}_{1}$ & 2.62 & 2.35 & 0.01 \\
\hline $\mathrm{M}_{3}-\mathrm{M}_{3}$ & 4.39 & 0.00 & 0.32 \\
\hline \multicolumn{4}{|c|}{ b. External body } \\
\hline SV & $8.19 * *$ & $21.16 * * *$ & 0.37 \\
\hline FL & $18.48 * * *$ & 3.52 & 0.37 \\
\hline FA & 0.01 & $9.55 * *$ & 0.05 \\
\hline TIB & $14.65 * * *$ & $3.91 *$ & 0.01 \\
\hline $\mathrm{HF}$ & 2.69 & 3.41 & 0.25 \\
\hline EAR & 0.71 & 1.09 & 0.39 \\
\hline TAIL & 1.24 & 2.47 & 0.14 \\
\hline
\end{tabular}



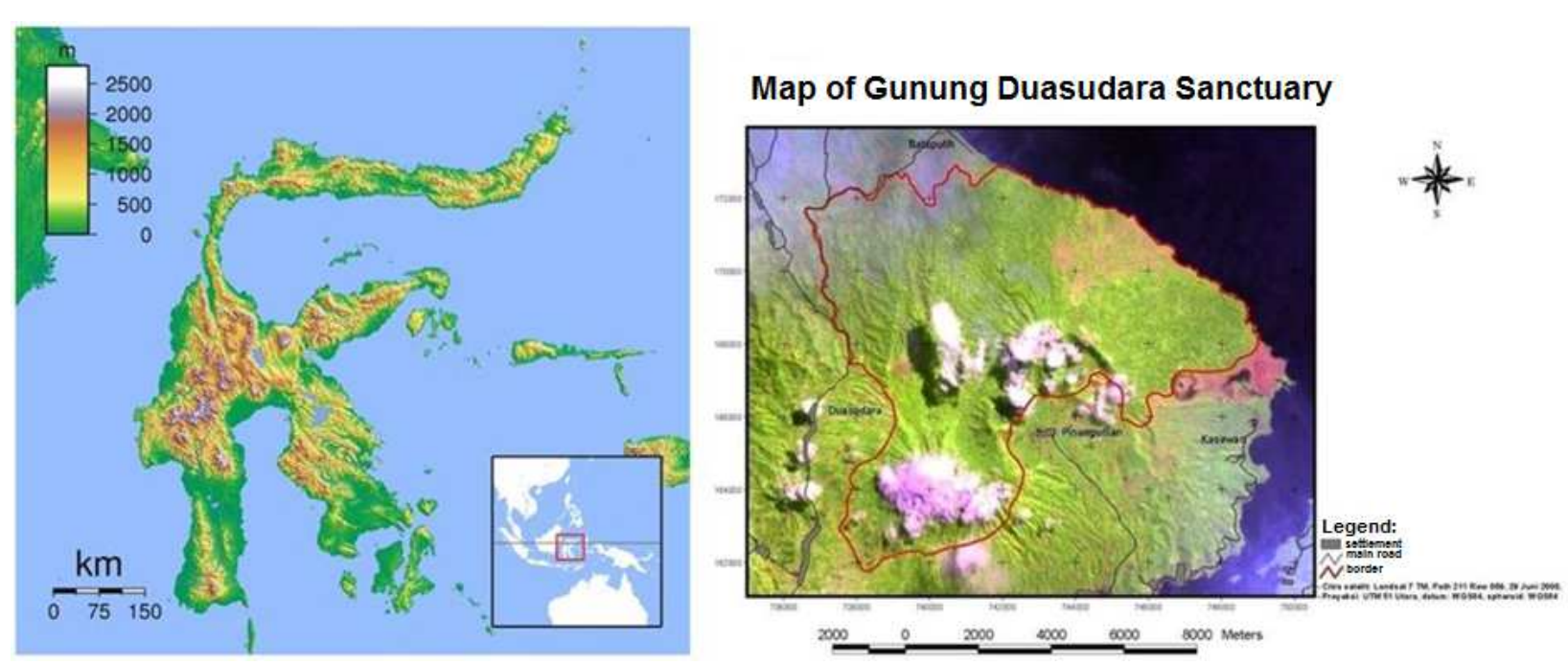

Fig. 1. Study site of genus Rousettus bat in Gunung Duasudara Sanctuary, North Sulawesi

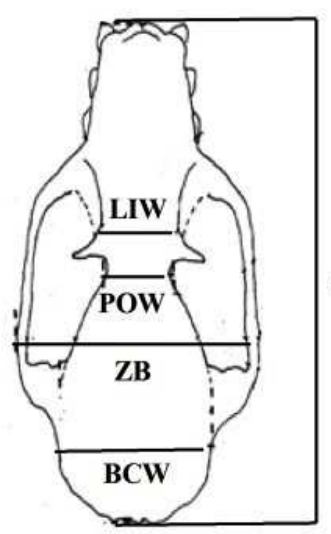

GSL
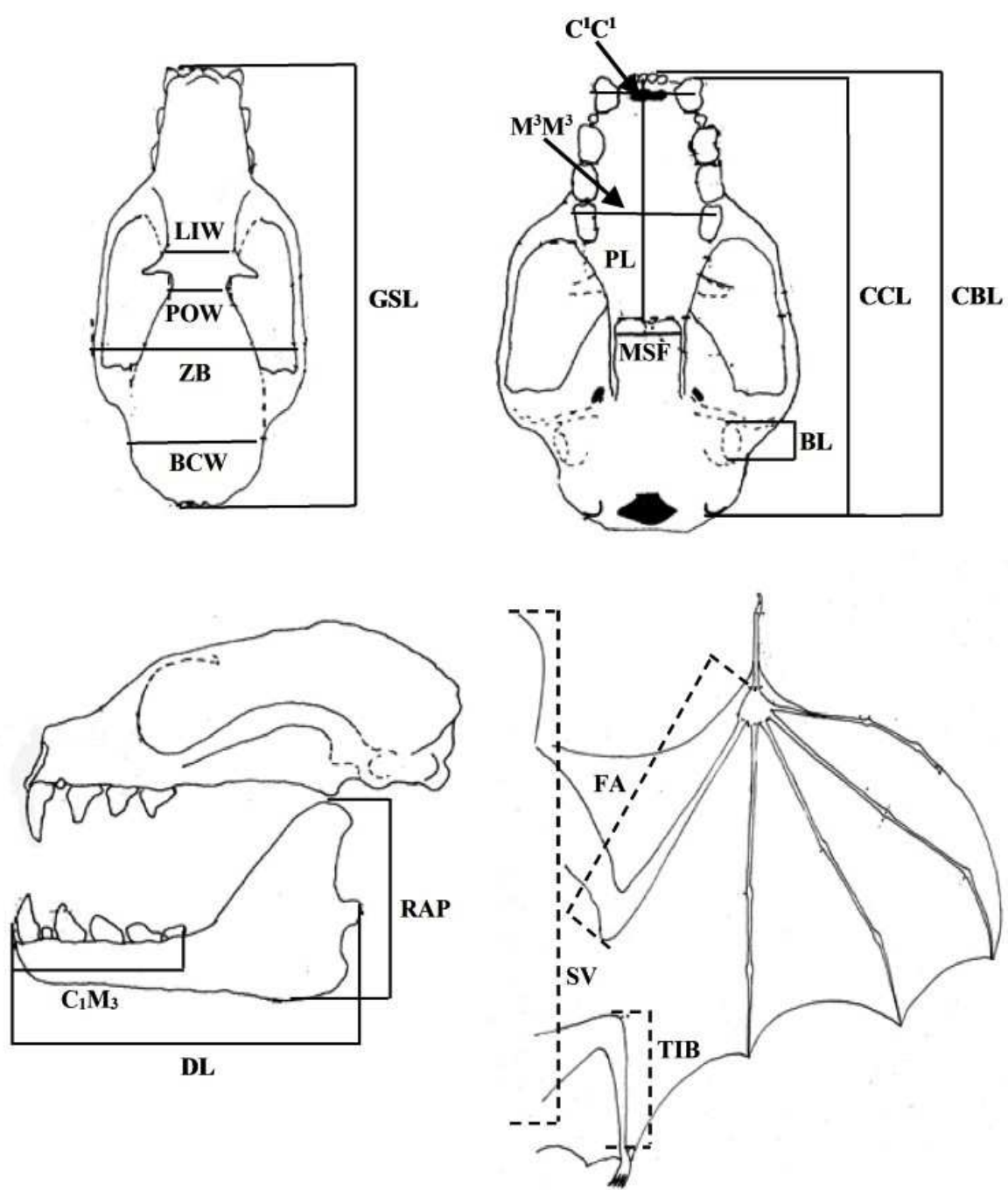

Fig 2. Measurements of skull and external body of genus Rousettus 
The skull characters measured were: (1) Greatest Skull Length (GSL), (2) Zygomatic Breadth (ZB), (3) Least Interorbital Width (LIW), (4) Postorbital Width (POW), (5) Braincase Width (BCW), (6) Bullae Length (BL), (7) Mesopterygoid Fossa Width (MSF), (8) Palatal Length (PL), (9) Condylobasal Length (CBL), (10) Condylocaninus Length (CCL), (11) distance between upper canine and third upper molar $\left(\mathrm{C}^{1} \mathrm{M}^{3}\right)$, (12) distance between outside upper canine $\left(\mathrm{C}^{1} \mathrm{C}^{1}\right)$, (13) distance between outside third upper molar $\left(\mathrm{M}^{3} \mathrm{M}^{3}\right)$, (14) Dentary Length (DL), (14) Ramus Angular Process (RAP), (15) distance between lower canine and third lower molar $\left(\mathrm{C}_{1} \mathrm{M}_{3}\right),(16)$ distance between outside lower canine $\left(\mathrm{C}_{1} \mathrm{C}_{1}\right)$ and (17) distance between outside third lower molar $\left(\mathrm{M}_{3} \mathrm{M}_{3}\right)$.

The external body characters measured were: (1) Snot-Vent length (SV), (2) Face Length (FL), (3) Forearm (FA), (4) Tibia (TIB), (5) Hindfoot Length (HF), (6) Ear (EAR) and (7) Tail (TAIL).

Each species was statistically tested based on 18 skull characters and 7 external body characters using ANOVA to determine the influence of Rousettus sp. sex to their morphological variations. Discriminant Function Analysis (DFA) was done by combining most of skull characters and all external body characters separately using species as priority group. This interspecific relationship in the discriminant function between skull characters and external body characters was highly similar. The DFA could also identify important characters in separating species/group. To minimize Wilk's Lambda value, there were only 6 characters were used (GSL, ZB, MSF, LIW, $\mathrm{C}^{1} \mathrm{C}^{1}$, FA).

\section{Results and Discussion}

Supp.Data.1 shows the value of sample size, mean, standard deviation, maximum and minimum of several skull and external body character measurements ( $\mathrm{mm}$ ) of genus Rousettus. It describe that $R$. celebensis has statistically the largest skull characters among three Rousettus species in this study. Despite only represented only by skull characters, $R$. celebensis is different from 2 other species. For example, the mean value of characters are:, GSL (37.30), ZB (22.20), BCW (14.48), MSF (5.07), PL (17.99), CBL (35.41), CCL (33.44), $\mathrm{C}^{1} \mathrm{M}^{3}$ (13.10), $\mathrm{C}^{1} \mathrm{C}^{1}$ (6.74), DL (27.67), $\mathrm{C}_{1} \mathrm{M}_{3}$ (14.17), $\mathrm{C}_{1} \mathrm{C}_{1}$ (4.09), respectively.

On the other hand, $R$. tangkokoensis n. sp. has smallest skull size However, this species has bigger size characters than $R$. amplexicaudatus and $R$. celebensis. The characters are: POW (8.99), FA (79.00), HF (22.33) and EAR (18.07).

$R$. amplexicaudatus has bigger characters than those of $R$. tangkokoensis n. sp. but smaller than those of $R$. celebensis for all characters, except for POW, FA, HF and EAR characters as previously mentioned.
Analysis of Variance (ANOVA) of sex influence upon entire skull and external body characters were measured in all genus shows that sex significantly influenced one skull character $\left(\mathrm{M}^{3} \mathrm{M}^{3}\right)$ and 3 external body characters (SV, FL, TIB) of $R$. amplexicaudatus $(p<0.05)$. It was influenced 5 skull characters (GSL, ZB, $\left.\mathrm{CBL}, \mathrm{C}^{1} \mathrm{C}^{1}, \mathrm{RAP}\right)$ and 3 external body characters (SV, FA and TIB) of $R$. celebensis. Yet it was influenced one skull character (MSF) of $R$. tangkokoensis n. sp. Thus, most of the analyzed skull characters and external body characters were not affected by sex. Therefore, both skull and external body characters of the three species were not sexually dimorphism (Table 1).

DFA used the species group represented by taxa $R$. amplexicaudatus, $R$. celebensis and $R$. tangkokoensis n. sp. DFA was initially done to all skull and external body characters that were not significantly influenced by sex. To avoid the "over fitting" to the DFA result, there were not all characters were employed. This study was used only 6 characters (GSL, ZB, MSF, LIW, $C^{1} C^{1}$, FA) selected to minimize the Wilk's Lambda value. Although the DFA of these three species groups had used reduce characters, the DFA value was similar to that using complete 25 skull and external body characters. This result was only based on 6 selected characters (Fig. 3 and Table 2).

The plot of genus Rousettus comprising 3 species, $R$. amplexicaudatus, $R$. celebensis and $R$. tangkokoensis n. $\mathrm{sp}$. on the basis of GSL, ZB, MSF, LIW, $\mathrm{C}^{1} \mathrm{C}^{1}$ and FA (Fig. 3). It is shows that those 3 species were dispersing, indicates that their kindship was close. The classification failures mostly occurred in $R$. amplexicaudatus. $R$. amplexicaudatus is close to either $R$. celebensis or $R$. tangkokoensis n. sp., so that some members of $R$. amplexicaudatus could be statistically misclassified as either $R$. celebensis or $R$. tangkokoensis n. sp. For $R$. celebensis and $R$. tangkokoensis n. sp. with sufficiently low similarity, these data did not result in error of species classification.

The DFA characters $(>0.5)$ set in function 1 are GSL, $\mathrm{ZB}, \mathrm{MSF}, \mathrm{LIW}, \mathrm{C}^{1} \mathrm{C}^{1}$ and FA and set in function 2 were GSL, ZB, MSF, LIW, $\mathrm{C}^{1} \mathrm{C}^{1}$ and FA (Table 2).

The DFA of the reduced characters was grouped into 2 significance functions explaining all variances. Function 1 explicates, whereas function 2 eludicates the variance with a total number of, respectively, 93.6 and $6.4 \%$ (Table 2 ). The data diversity of function 1 is higher than that of function 2 , it shows that various morphological differences involving skull and external body characters are entirely an important character in separating members of genus Rousettus. These morphological groups are considered having different specifications, since these 3 species of genus Rousettus possess different skull and external body characters one to another. 
Table 2. Standard and unstandard discriminant function coefficient of 3 species of genus Rousettus

\begin{tabular}{lll}
\hline Character & Function 1 & Function 2 \\
\hline GSL & $-1.129(-0.632)$ & $0.257(0.144)$ \\
ZB & $0.378(0.245)$ & $-0.141(-0.091)$ \\
MSF & $-0.282(-0.754)$ & $-0.096(-0.258)$ \\
LIW & $0.445(0.964)$ & $1.201(2.601)$ \\
C $^{1}$ & $-0.117(-0.179)$ & $-0.612(-0.937)$ \\
FA & $0.799(0.228)$ & $-0.209(-0.060)$ \\
Eigen Value & 1.806 & 0.113 \\
Constant & -2.150 & -10.451 \\
Variance explained (\%) & 93.6 & 6.4 \\
\hline
\end{tabular}

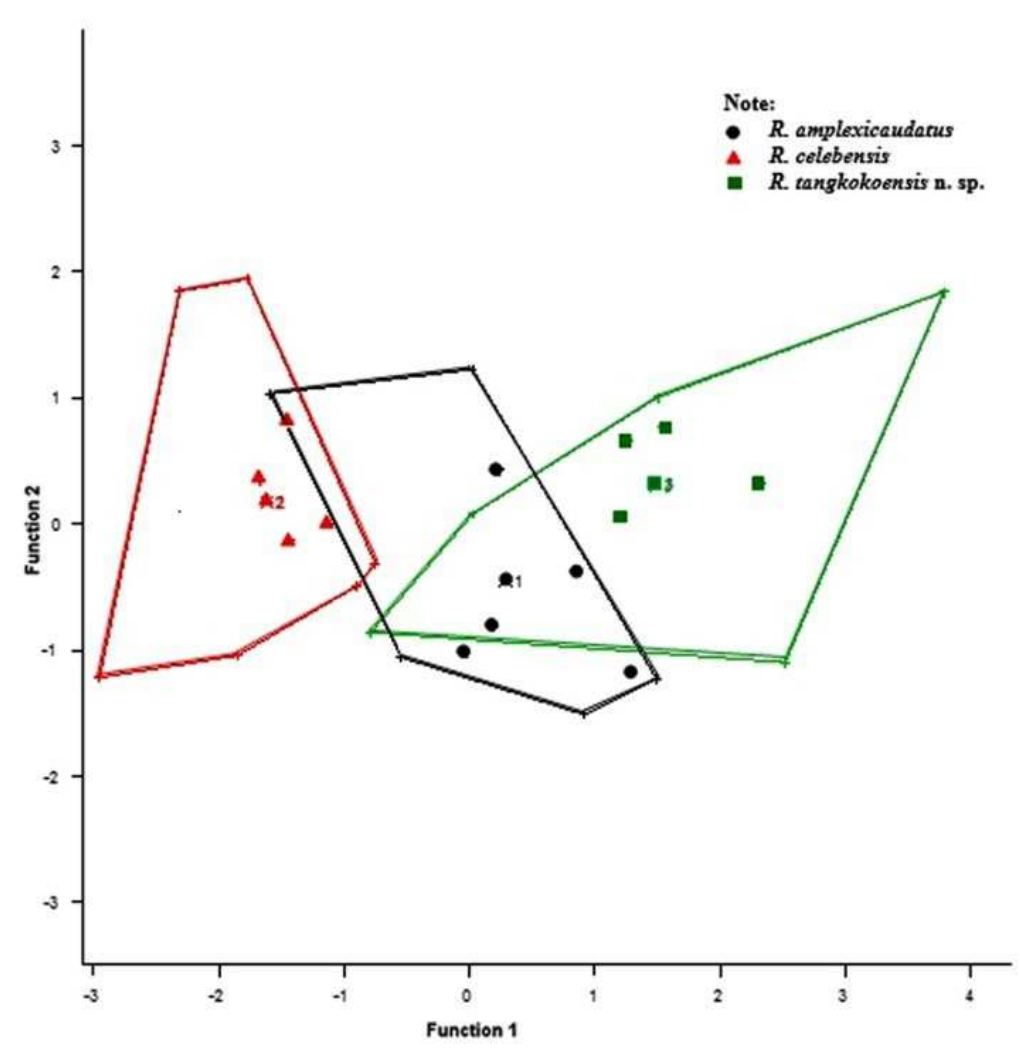

Fig. 3. Discriminant function 1 and 2 plot of genus Rousettus based on 6 selected characters

\section{Species Sistematics}

- Class: Mammal

- Order: Chiroptera

- Suborder: Megachiroptera

- Family: Pteropodidae Gray, 1821

- Genus: Rousettus Gray, 1821

\section{Rousettus Amplexicaudatus Saint-Hilaire (1810)}

\section{Holotype}

Hanry Lengkong collected specimen from Manado, Indonesia (HL) 11131 (field no. RA-2). It was caught on November $7^{\text {th }} 2013$ over the grassland, at $14 \mathrm{~m}$ above the sea level, Gunung Duasudara Sanctuary, North Sulawesi,
Indonesia ( $\mathrm{N} 01^{0} 32,262^{\prime}$, E $\left.125^{\circ} 12,281^{\prime}\right)$. The specimen was adult male, testes swollen, 74 grams BW, skull and dentary separated. Fresh specimens were preserved in $70 \%$ alcohol, meters

\section{Parasitype}

Nine specimens were collected by Hanry lengkong from moss forest, submontana forest, owl and forest, casuarine forest, coastal forest, shrub and grassland near the holotype location.

The specimens were:

- HL11132 (field no. RA-19): adult male, testes swollen, 73 grams BW, caught at $15 \mathrm{~m}$ above sea level (N 010 $32,883^{\prime}$, E $\left.125^{\circ} 12,543^{\prime}\right)$ 
- HL 11133 (field no. RA-62): Adult female, unswollen nipples, 66 grams BW, caught at $192 \mathrm{~m}$ above sea level ( $\mathrm{N}^{0} 30,872^{\prime}$, E $125^{\circ} 13,516^{\prime}$ )

- HL11134 (field no. RA-77): Adult female, unswollen nipples, 54 grams BW, caught at 1.109 $\mathrm{m}$ above sea level (N $01^{0} 31,115^{\prime}$, E $\left.125^{\circ} 11,093^{\prime}\right)$

- HL 11135 (field no. RA-78): Adult male, unswollen testes, 67 grams BW, caught at 1.109 $\mathrm{m}$ above sea level (N $01^{0} 31,115^{\prime}$, E $125^{\circ} 11,093^{\prime}$ )

- HL 11136 (field no. RA-113): Adult male, unswollen testes, 59 grams BW, caught at $55 \mathrm{~m}$ above sea level (N 01 ${ }^{0} 33,429^{\prime}$, E $125^{\circ} 09,359^{\prime}$ )

- HL 11137 (field no. RA-140): Adult male, slightly swollen testes, 65 grams $\mathrm{BW}$, caught at $514 \mathrm{~m}$ above sea level ( $\mathrm{N} 01^{0} 30,872^{\prime}$, E $125^{0} 13,516^{\prime}$ )

- $\quad$ HL 11138 (field no. RA-145), adult female, swollen nipples without bite marks, 69 grams BW, caught at $514 \mathrm{~m}$ above sea level ( $\mathrm{N} 01^{0} 30,872^{\prime}$, E $\left.125^{0} 13,516^{\prime}\right)$

- HL 11139 (field no. RA-153), adult female, swollen nipples without out bite marks, 94 grams BW, caught at $824 \mathrm{~m}$ above sea level (N $01^{0} 31,505^{\prime}, \mathrm{E}$ $\left.125^{0} 11,117^{\prime}\right)$

- HL 111310 (field no. RA-158), adult female, unswollen nipples, 54 grams BW, caught at $712 \mathrm{~m}$ above sea level ( $\mathrm{N} 01^{0} 31,193$ ', E $125^{\circ} 12,266^{\prime}$ )

\section{Distribution}

The specimens were found in Gunung Duasudara Sanctuary, North Sulawesi, Indonesia.

\section{Diagnosis}

$R$. amplexicaudatus has bigger size than average of $R$. tangkokoensis n. sp. but smaller than the average of $R$. celebensis for all characters, including POW, FA, HF and EAR (Table 1).

\section{Description}

All bats were described directly in the sanctuary of Gunung Duasudara. R. amplexicaudatus specimen was compared with $R$. celebensis and $R$. tangkokoensis $\mathrm{n}$. sp. (Fig. 1).

\section{Pelage}

The color of shoulder pelage was greyish brown to brown, chest to belly was slightly bright grey brown, neck was gery brown with yellow hair bundle on both neck sides, top of head was slightly dark grey brown. There was no dense hair up to around the thigh, the wing is hairy and no wing attached onto shoulder side.

\section{External Body}

R. amplexicaudatus bats possessed longer SV, FL, TIB and TAIL than $R$. celebensis and $R$. tangkokoensis n. sp.; meanwhile the FA, HF and EAR are bigger than those of $R$. celebensis but smaller than those of $R$. tangkokoensis n. sp .

\section{Skull}

R. amplexicaudatus had longer GSL, BL, LIW and POW than those in $R$. celebensis and $R$. tangkokoensis n. sp.; meanwhile the ZB, BCW, MSF, PL, CBL and CCL are bigger than those in $R$. tangkokoensis $\mathrm{n}$. sp. but smaller than those in $R$. celebensis.

\section{Teeth and Dentary}

$R$. amplexicaudatus specimen had longer $\mathrm{M}_{3} \mathrm{M}_{3}$, $\mathrm{M}^{3} \mathrm{M}^{3}$ and RAP than $R$. celebensis and $R$. tangkokoensis n. sp.; the $\mathrm{C}^{1} \mathrm{M}^{3}, \mathrm{C}_{1} \mathrm{M}_{3}, \mathrm{C}^{1} \mathrm{C}^{1}, \mathrm{C}_{1} \mathrm{C}_{1}$ and $\mathrm{DL}$ are also bigger than those in $R$. tangkokoensis n. sp. but smaller than those in $R$. celebensis.

\section{Biological Condition}

Ninety-eight adult males possessed reproductive condition (63 unswollen testes, 9 slightly swollen testes and 26 swollen testes) and 126 adult females had reproductive condition (60 unswollen nipples, 16 slightly swollen, 23 swollen nipples without bite marks, 24 swollen nipples with bite marks and 3 pregnant).

\section{Habitat}

Two-hundred seventy-nine bats were caught using bat nets at 1 and $3 \mathrm{~m}$ above the ground in moss forest, submontana forest, lowland forest, casuarine forest, shrub and grassland in rainy and dry seasons.

\section{Rousettus Celebensis Andersen (1907)}

\section{Holotype}

Hanry Lengkong collected the specimens from Manado, Indonesia (HL) 111311 (field no. RC-1). It was caught on December $6^{\text {th }}, 2013$, in moss vegetation, at $1.037 \mathrm{~m}$ above sea level, Gunung Duasudara Sanctuary, North Sulawesi, Indonesia (N $\left.01^{0} 31,271^{\prime}, \mathrm{E} 125^{\circ} 11,169^{\prime}\right)$. The specimens were adult male, unswollen testes, 44 grams BW. Skull and dentary were seperated then preserved in $70 \%$ alcohol.

\section{Parasitype}

Nine specimens were collected by Hanry lengkong from vegetations of moss forest, submontana forest, lowland forest, casuarine forest, coastal forest, shrub and grassland near the holotype location.

The specimens were: 
- HL111312 (field no. RC-84), adult female, swollen nipples without bite marks, 41 grams BW, caught at $1.109 \mathrm{~m}$ above sea level ( $\mathrm{N} 01^{0} 31,115^{\prime}$, E $\left.125^{0} 11,093^{\prime}\right)$

- HL 111313 (field no. RC-94), adult male, slightly swollen testes), 95 grams BW, caught at $1.109 \mathrm{~m}$ above sea level (N $01^{0} 31,115$, E $125^{0} 11,093$ ')

- HL111314 (field no. RC-129), adult female, unswollen nipples, 42 grams BW, caught at $996 \mathrm{~m}$ above sea level (N 01 ${ }^{\circ} 30,809^{\prime}$, E $\left.125^{\circ} 11,076^{\prime}\right)$

- HL 111315 (field no. RC-137), adult male, slightly swollen testis, 90 grams BW, caught at $712 \mathrm{~m}$ above sea level (N 01031,193', E $125^{0} 12,266^{\prime}$ )

- HL 111316 (field no. RC-173), adult female, unswollen nipples, 55 grams BW, caught at $514 \mathrm{~m}$ above sea level (N 01030,872', E 125 13,516')

- HL 111317 (field no. RC-190), adult male, unswollen testes, 75 grams BW, caught at $389 \mathrm{~m}$ above sea level ( $\mathrm{N} 01^{0} 30,620^{\prime}$, E $125^{\circ} 13,201^{\prime}$ )

- HL 111318 (field no. RC-198), adult female, unswollen nipples, 58 grams BW, caught at 1.351 $\mathrm{m}$ above sea level (N $01^{0} 28,991$ ', E $\left.125^{\circ} 10,291^{\prime}\right)$

- HL 111319 (field no. RC-199), adult male, unswollen testes, 67 grams BW, caught at 1.345 m above sea level ( $\mathrm{N} 01^{0} 29,022^{\prime}$, E $\left.125^{\circ} 10,344^{\prime}\right)$

- HL 111320 (field no. RC-204), adult female, unswollen nipples, 56 grams BW, caught at $55 \mathrm{~m}$ above sea level (N 01 ${ }^{0} 33,429^{\prime}$, E $\left.125^{\circ} 09,359^{\prime}\right)$

\section{Distribution}

Those specimens found in Gunung Duasudara Sanctuary, North Sulawesi, Indonesia.

\section{Diagnosis}

$R$. celebensis has the biggest skull and external body characters. It is different from $R$. amplexicaudatus and $R$. tangkokoensis $\mathrm{n}$. sp. since it possesses many larger characters despite represented only by the following skull characters, including: GSL of $37.30, \mathrm{ZB}$ of 22.20 , $\mathrm{BCW}$ of $14.48, \mathrm{MSF}$ of 5.07 , PL of $17.99, \mathrm{CBL}$ of $35.41, \mathrm{CCL}$ of $33.44, \mathrm{C}^{1} \mathrm{M}^{3}$ of $13.10, \mathrm{C}^{1} \mathrm{C}^{1}$ of 6.74 , DL of 27.67, $\mathrm{C}^{1} \mathrm{M}^{3}$ of $14.17, \mathrm{C}^{1} \mathrm{C}^{1}$ of 4.09 (Table 1).

\section{Description}

All bats were described directly in Gunung Duasudara Sanctuary. $R$. celebensis specimen was compared with that of $R$. amplexicaudatus and $R$. tangkokoensis n. sp. (Fig. 4).

\section{Pelage}

The color of shoulder pelage was brown to yellowish brown, chest to belly was slightly bright yellowish brown, neck was dark orange, top head was slightly dark yellowish brown. They had dense pelage around the thigh, hairy wings and no wing attaching on to the shoulder side.

\section{External Body}

R. celebensis had shorter SV, FA, TIB, HF and EAR than those in $R$. amplexicaudatus and $R$. tangkokoensis n. sp.; FL and TAIL are longer than those in $R$. tangkokoensis n. sp., but smaller than those in $R$. amplexicaudatus.

\section{Skull}

R.celebensis had longer GSL, ZB, BCW, BL, MSF, $\mathrm{PL}, \mathrm{CBL}$ and CCL than those in $R$. amplexicaudatus and $R$. tangkokoensis n. sp.; meanwhile the LIW was larger than that in $R$. tangkokoensis n. sp. but smaller than that in $R$. amplexicaudatus; POW was larger than that in $R$. amplexicaudatus but smaller than that in $R$. tangkokoensis $\mathrm{n}$. sp.

\section{Teeth and Dentary}

R. celebensis had longer $\mathrm{C}^{1} \mathrm{M}^{3}, \mathrm{C}_{1} \mathrm{M}_{3}, \mathrm{C}^{1} \mathrm{C}^{1}, \mathrm{C}_{1} \mathrm{C}_{1}$ and $\mathrm{DL}$ than those in $R$. tangkokoensis n. sp. and $R$. amplexicaudatus; the $\mathrm{M}^{3} \mathrm{M}^{3}, \mathrm{M}_{3} \mathrm{M}_{3}$ and RAP were bigger than those in $R$. tangkokoensis $\mathrm{n}$. sp. but smaller than those in $R$. amplexicaudatus.

\section{Biological Condition}

Ninety adult males had reproductive condition (76 had unswollen testes, 3 had slightly swollen testes and 11 had swolllen testes) and 123 adult females had reproductive condition (76 had unswollen nipples, 9 had slightly swollen nipples and 20 had swollen nipples without bite marks, 9 had swollen nipples with bite marks and 9 pregnant).

\section{Habitat}

Two-hundred sixty-one individuals were caught one time in rainy and dry seasons by using bat nets at 1 and 3 $\mathrm{m}$ above the ground in moss forest, submontana forest, lowland forest, casuarine forest, coastal forest and shrub.

\section{Rousettus Tangkokoensis new. sp.}

\section{Holotype}

Hanry Lengkong was collected the specimens from Manado, Indonesia (HL) 111321 (field no.RT-1). It was caught on June $5^{\text {th }}, 2013$, lowland forest at $514 \mathrm{~m}$ above sea level, Gunung Duasudara Sanctuary, North Sulawesi, Indonesia ( $01^{0} 30,872$ ', E $\left.125^{\circ} 13,516^{\prime}\right)$. The specimes were adult female, swollen nipples with bite marks), 84 grams BW. Their skull and dentary were separated then preserved in $70 \%$ alcohol. 

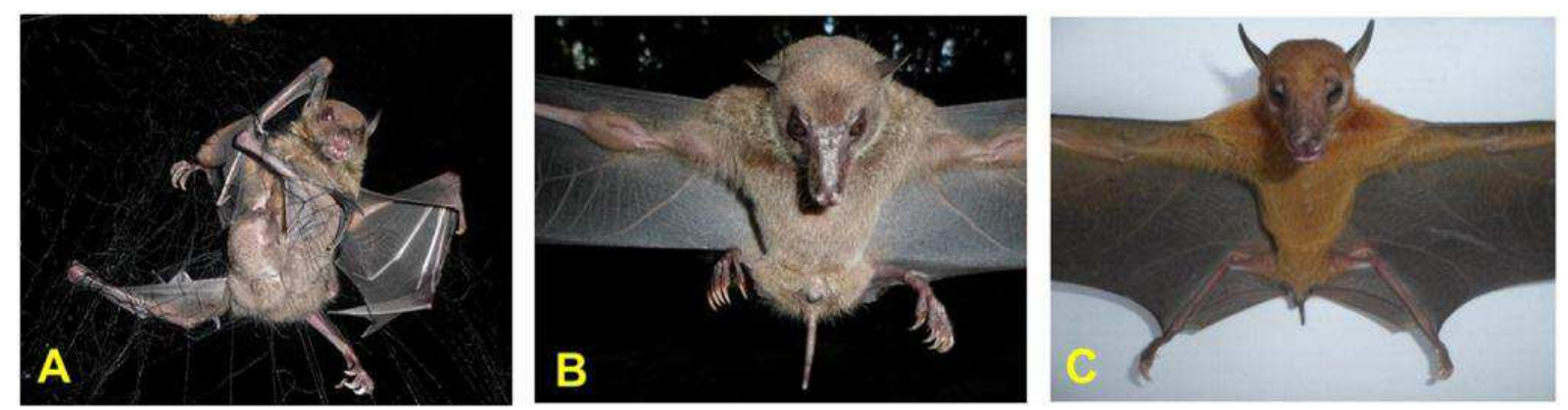

Fig. 4. Bat species: (a) Rousettus amplexicaudatus, (b) Rousettus celebensis and (c) Rousettus tangkokoensis n. sp.

\section{Parasitype}

Eight specimen collected by Hanry lengkong in lowland forest and coastal forest near holotype location. The specimens were:

- HL 111322 (field no. RT-2): adult female, unswollen nipples, 72 grams BW, caught at $495 \mathrm{~m}$ above sea level ( $\mathrm{N} 01^{0} 30,779^{\prime}, \mathrm{E} 125^{\circ} 13,543^{\prime}$ )

- HL 111323 (field no. RT-3): adult male, swollen testes, 86.0 grams BW, caught at $514 \mathrm{~m}$ above sea level ( $\mathrm{N} \mathrm{01}{ }^{0} 30,872$ ', E $125^{\circ} 13,516^{\prime}$ )

- HL 111324 (field no. RT-4): adult female, unswollen nipples, 72 grams BW, caught at $514 \mathrm{~m}$ above sea level (N $01^{0} 30,872^{\prime}$, E $125^{0} 13,516^{\prime}$ )

- HL 111325 (field no. RT-5), adult male, swollen testes, 83 grams BW, caught at $514 \mathrm{~m}$ above sea level ( $\mathrm{N} 01^{0} 30,872$ ', E $\left.125^{\circ} 13,516^{\prime}\right)$

- HL 111326 (field no. RT-6), adult female, swollen nipples with bite marks), 83 grams $\mathrm{BW}$, caught at $514 \mathrm{~m}$ above sea level ( $\mathrm{N} 01^{0} 30,872^{\prime}, \mathrm{E}$ $\left.125^{0} 13,516^{\prime}\right)$

- HL 111327 (field no. RT-7), adult male, unswollen testes, 77 grams $\mathrm{BW}$, caught at $514 \mathrm{~m}$ above sea level (N 01 $30,872^{\prime}$, E $125^{\circ} 13,516^{\prime}$ )

- HL 111328 (field no. RT-8), adult female, swollen nipples without bite marks, 82 grams BW, caught at $514 \mathrm{~m}$ above sea level (N 01030,872', E $\left.125^{0} 13,516^{\prime}\right)$

- HL 111329 (field no. RT-9), adult male, unswollen testes, 72 grams BW, caught at $192 \mathrm{~m}$ above sea level (N $01^{0} 30,872^{\prime}$, E $\left.125^{\circ} 13,516^{\prime}\right)$

\section{Ethimology}

The new species which is proposed using the name of Tangkoko Mt. occuring in the sanctuary area was collected by Hanry Lengkong from Manado, Indonesia. The new species is (HL) 111321 had been found in Gunung Duasudara, which the only area known where this species was collected.

\section{Diagnosis}

The color of outer appearance of R. tangkokoensis $\mathrm{n}$. sp. was blackish orange shoulder, while $R$. amplexicaudatus was greyish brown to brown and $R$. celebensis was brown to yellowish brown. The color of chest to belly of $R$. tangkokoensis $\mathrm{n}$. sp. was slightly bright orange, while $R$. amplexicaudatus was slightly bright grey brown and $R$. celebensis was slightly yelowish brown. The top head of R. tangkokoensis n. sp. was colored slightly dark orange, while $R$. amplexicaudatus was slightly dark grey brown and $R$. celebensis was slightly yellowish brown. The neck of $R$. tangkokoensis n. sp. was colored dark orange, while $R$. amplexicaudatus was grey brown with yellow hair bundle on both sides of the neck and $R$. celebensis was dark orange.

The pelage of $R$. tangkokoensis $\mathrm{n}$. sp. and $R$. amplexicaudatus was similar since it did not possessing dense pelage up to around the thigh, while $R$. celebensis had dense pelage around the thigh. Next similarity between $R$. tangkokoensis n. sp., R. amplexicaudatus and $R$. celebensis is they had hairy wings attaching on the back side, not on the their shoulder sides (Fig. 4).

$R$. tangkokoensis $\mathrm{n}$. sp. had bigger and smaller skull characters than those in $R$. amplexicaudatus and $R$. celebensis. The former is POW $(8.99 \mathrm{~mm} ; 8.60-9.70$ $\mathrm{mm})$; the latter is GSL $(34.67 \mathrm{~mm} ; 30.30-37 \mathrm{~mm})$. The other characters are ZB $(20.79 \mathrm{~mm}$; $18.00-24.40 \mathrm{~mm})$, LIW (7.18 mm; 6.70-8.30 mm), BCW (14.15 mm; 13.70-14.70 mm), BL (2.60 mm; 2.40-2.80 mm), MSF (4.54 mm; 4.10-5.00 mm), PL (16.34 mm; 14.60-17.60 $\mathrm{mm})$, CBL (33.11 mm; 28.00-36.50 mm), CCL (31.84 $\mathrm{mm} ; 27.50-34.90 \mathrm{~mm}), \mathrm{C}^{1} \mathrm{M}^{3}$ (11.27 mm; 9.30-12.60 $\mathrm{mm}), \mathrm{C}^{1} \mathrm{C}^{1}\left(6.12 \mathrm{~mm}\right.$; 5.50-7.30 mm), $\mathrm{M}^{3} \mathrm{M}^{3}$ (9.13 mm; 8.80-9.80 mm), DL (25.72 mm; 23.00-28.30 mm), RAP width $(10.38 \mathrm{~mm}$; $9.50-11.80 \mathrm{~mm}), \mathrm{C}_{1} \mathrm{M}_{3}(12.33 \mathrm{~mm}$; $10.10-14.90 \mathrm{~mm}), \mathrm{C}_{1} \mathrm{C}_{1}(3.79 \mathrm{~mm} ; 3.50-4.20 \mathrm{~mm})$ and $\mathrm{M}_{3} \mathrm{M}_{3}(8.84 \mathrm{~mm} ; 8.20-9.50 \mathrm{~mm})$.

The external body characters of $R$. tangkokoensis $\mathrm{n}$. sp., (FA, HF, EAR and TAIL) were bigger than those of $R$. amplexicaudatus and $R$. celebensis. Furthermore, SV distance of $R$. tangkokoensis $\mathrm{n}$. $\mathrm{sp}$. is also bigger than that of $R$. celebensis. TIB of $R$. tangkokoensis $\mathrm{n}$. sp. is 
bigger than $R$. amplexicaudatus. Otherwise, the FL of $R$. tangkokoensis $\mathrm{n}$. $\mathrm{sp}$. is smaller than $R$. amplexicaudatus. Overall, $R$. tangkokoensis $\mathrm{n}$. $\mathrm{sp}$. had small-sized characters, except for POW, FA, HF and EAR, which are bigger than those of $R$. amplexicaudatus and $R$. celebensis (Table 1).

Beside differences among species above, Suyanto (2001) stated that these were only based on the size lower arm wing and the presence or absence of wing attaching on the middle of shoulder. In both characters, $R$. tangkokoensis $\mathrm{n}$. $\mathrm{sp}$. is consistent with typical characteristics of Rousettus. Under this reason, the species is classified in a member of Rousettus.

Comparing $R$. tangkokoensis $\mathrm{n}$. sp. with other studies on $R$. amplexicaudatus based on one the body sizes, their FA length is about 82.22-86.76 mm (Payne and Francis, 1985) and FA length is about 77-87.2 mm (Suyanto, 2001). Apparently, the R. tangkokoensis n. sp. is nearly similar to $R$. amplexicaudatus.

Bergmans and Rosendaal (1988) measured 14 male $R$. amplexicaudatus from Sulawesi. Their FA length is about 81.55 (77.3-85.6 mm), ZB length is $22.3(20.7-23.3 \mathrm{~mm})$, GSL length is $36.85(35.2-38.5 \mathrm{~mm})$ and CBL length is $35.4(34.2-37.2 \mathrm{~mm})$. It is apparently $R$. amplexicaudatus have similarity with the $R$. tangkokoensis n. sp body size, yet it has bigger skull than $R$. tangkokoensis $\mathrm{n}$. sp., but with $R$. spinalatus, it had similar FA, $85.1 \mathrm{~mm}$.

Maryanto and Yani (2003) measured the several characters of 12 males $R$. celebensis in Museum Zoologicum Bogoriense and determinded their length for these several characters: FA $75.81 \mathrm{~mm}$ (72.61$79.41 \mathrm{~mm})$, GSL $39.46 \mathrm{~mm}(38.75-40.64 \mathrm{~mm})$, ZB $23.59 \mathrm{~mm}(22.02-25.12 \mathrm{~mm})$, CBL $37.57 \mathrm{~mm}$ (36.48$38.66 \mathrm{~mm})$ and POW $7.69(7.26-8.47 \mathrm{~mm})$. They also measured the several characters from 4 males $R$. linduensis from Sulawesi. The measured ofthe length for these characters were: FA $76.73 \mathrm{~mm}$ (75.64-77.54 $\mathrm{mm})$, GSL $39.38 \mathrm{~mm}(38.81-39.70 \mathrm{~mm})$, ZB 24.08 $\mathrm{mm}(23.93-24.25 \mathrm{~mm})$, CBL $37.47 \mathrm{~mm}$ (37.2-37.63 $\mathrm{mm})$ and POW $7.07 \mathrm{~mm}(7.02-7.14 \mathrm{~mm})$. In ferential, $R$. celebensis and $R$. linduensis have smaller body size and entirely larger skull, except the POW size.

Rookmaker and Bergmans (1981) measuerd the body size of $R$. leschenaultii from Indonesia. $R$. tangkokoensis n. sp. has smaller body size and skull compared with $R$. leschenaultii. R. leschenaultii has FA length about 84.0$90.36 \mathrm{~mm}$, GSL 40.3-43.6 $\mathrm{mm}$ and ZB 24.8-27.6 mm, respectively.

Moreover, $R$. tangkokoensis n. sp. compared with $R$. egyptiacus (FA of 85-101.9 mm) (Grzimek, 2003; Kwiecinski and Griffin, 1999) and R. madagascar (FA of 119-140 mm) (Bergmans, 1997; Bush Warriors, 2013; Jenkins and Racey, 2008; McNab, 1969), it is apparent that $R$. tangkokoensis n. sp. be smaller than $R$. egyptiacus and R. madagascar.

\section{Description}

All bats were described directly in Gunung Duasudara Sanctuary. R. tangkokoensis n. sp. specimens were compared with those of $R$. amplexicaudatus and $R$. celebensis.

\section{Pelage}

The color of shoulder pelage is blackish orange to orange, chest to belly is slightly bright, neck is dark orange, top head is slightly dark orange. There is no dense pelage around the thigh. They have unhairy wings and no wing attaching on the shoulder sides.

\section{External Body}

R. tangkokoensis n. sp. has longer FA, HF, EAR. They have smaller FL and shorter TAIL than those of $R$. amplexicaudatus and $R$. celebensis and longer Snot-Vent (SV) than that of $R$. celebensis.

\section{Skull}

R. tangkokoensis n. sp. has big POW and small GSL, ZB, LIW, BCW, BL, MSF, PL, CBL and CCL.

\section{Teeth and Dentary}

R. tangkokoensis $\mathrm{n}$. sp. has small $\mathrm{C}^{1} \mathrm{M}^{3}$, small $\mathrm{C}_{1} \mathrm{M}_{3}$, small $\mathrm{C}^{1} \mathrm{C}^{1}$, small $\mathrm{C}_{1} \mathrm{C}_{1}$, small $\mathrm{M}^{3} \mathrm{M}^{3}$, small $\mathrm{M}_{3} \mathrm{M}_{3}$, short DL and small RAP.

\section{Biological Condition}

Four male specimens have reproductive condition (two of them have unswollen testes and the rest have swollen testes) and 5 adult female specimens have reproductive condition (two have unswollen nipples, 1 have swollen nipples without bite mark and 2 have swollen nipples with bite marks).

\section{Habitat}

Nine bats were caught when rainy and dry seasons using bat nets at 1 and $3 \mathrm{~m}$ above the ground in lowland forest and coastal forest.

\section{Discussion}

New bat species was found in Sulawesi. There have been 5 species known more than those of other islands in Indonesia or any other areas. It proves that Sulawesi island has high diversity of bats and as (Lee et al., 2001) a hot spot (natural habitat) (Maryanto and Yani, 2003) of this genus. North Sulawesi is the only wellknown natural habitat of Rousettus (Boneia) bidens, Central Sulawesi is the well-known natural habitat of Rousettus linduensis.

In fact, the bats were hunted local people consumption or were saled in the market in North Sulawesi and other areas. That could caused seriously hazard for the entire species and endanger the study basis 
on bats in this island which has unique evolutionary perspectives. In Gunung Duasudara Sanctuary, specifically, there are 12 active hunting areas, including the caves and tree holes where the bats are usually found. Thus, sustainability of bat population in Indonesia could be developed by environmental awareness of bat hunters, tour guide and local communities. Government involvement is also expected in the case of law enforcement of natural habitats protections against illegal bat hunters. Gunung Duasudara Sanctuary needs to be protected due to its unique ecosystem, the presence of endangered species, high natural diversity, the potential function of hydrological protection and natural tourism destination.

This study was conducted in all types of vegetations at the range of altitude $0-1351 \mathrm{~m}$ above sea level, inluded moss forest, submontana forest, lowland forest, casuarine forest, coastal forest, shrub and grassland. Nevertheless, $R$. tangkokoensis $\mathrm{n}$. sp. was only found in lowland forest ( 8 types) and coastal forest (one type) at $0-600 \mathrm{~m}$ above sea level. This species was considered as lowland origin adjacent to casuarine forest of Batuangus Mt., with many genera. Bats could be found in various places possessing vegetated terrestrial ecosystem. Lowland forest is a typical forest holding the highest biodiversity over other types of forests (Medellín et al., 2000). Our research revealed that the area was very important for bats to make a nest and fulfilling their diet due to the availability of preferred food, such as kongkoriang tree (Adinandra dumosa vidal) and council tree (Ficus altissima). These trees bearing fruits in May to June so that $R$. tangkokoensis n. sp. is only found in lowland forest and coastal forest during that periode. It is important that the government establish the zonation to protect bat habitats, especially lowland forest and coastal forest. In this study, there were found possessing high bat diversity and the places where new species was identified. Major concerns on this location are hunting, deforestation and land conversion to coconut plantation area.

$R$. tangkokoensis n. sp. was different from other Rousettus since it has blackish orange to orange colored shoulder, orange colored chest to belly, dark orange colored neck, darker orange colored top head, unhairy wing attaching on shoulder sides, big and wide FA and large POW. The influence of sex type on all measured parameters using ANOVA. R. amplexicaudatus had one skull character $\left(\mathrm{M}^{3} \mathrm{M}^{3}\right)$ and 3 external body characters (SV, FL and TIB) significantly affected; $R$. celebensis had 5 skull characters (GSL, ZB, CBL $\mathrm{C}^{1} \mathrm{C}^{1}$ and RAP); and 3 external body characters (SV, FA and TIB) significantly affected; and $R$. tangkokoensis n. sp. has only one skull character (MSF) significantly affected. It means that there is no sexual dimporphism.

The morphology of $R$. tangkokoensis n. sp. was distinguished from $R$. amplexicaudatus and $R$. celebensis based on 2 significance functions. Function 1 describes the variation represented by total number of $93.6 \%$ and function 2 explains the variation represented by $6.4 \%$ (Table 2). It shows that data diversity of function 1 is higher than that of function 2, refers that various morphological differences involving the entire skull size and external body were an important character to distinguish the members of genus Rousettus.

\section{Conclusion}

Three species of genus Rousettus have morphological differences involving the entire skull size and external body. There was discovered that sex type had influenced the skull and external body characters on $R$. amplexicaudatus, $R$. tangkokoensis n. sp. and $R$. celebensis. However, most of other characters were statistically not-significant that indicated there was not any sexual dimorphism.

\section{Acknowledgement}

Many people have contributed to this research completion. We would specifically appreciated Jopy, Pipo, Johanes, Budi, Nyong and Anto, for the support of bat specimen collection in Gunung Duasudara Sanctuary, North Sulawesi. We would thank to Mahadaratunkamsi as well in measurement and identification techniques during our work in Biological Research and Development Center- LIPI Bogor.

\section{Author's Contributions}

Hanry Jefry Lengkong: Participates in all experiment, coordinated the data-analysis and contributed to the writing manuscript.

Endang Arisoesilaningsih, Luchman Hakim and Sudarto: Designed the research plan, organized the study and contributed to the writing manuscript.

\section{Ethics}

This article is original and contains unpublished material. The corresponding author confirms that all of the other authors have read and approved the manuscript and no ethical issues involved.

\section{References}

Andersen, K., 1907. On pterocyon, rousettus and myonycteris. Ann. Mag. Nat. Hist., 19:501-515.

Andersen, K., 1912. Catalogue of the Chiroptera in the Collection of the British Museum. 2nd Edn., British Museum Publications, London, pp: 854.

Bergmans, W. and F.G. Rozendaal, 1988. Notes on a collection of fruit bats from Sulawesi and some offlying islands 9 Mammalia, Megachiroptera). Zoologische Verhandelingen, 248: 1-14. 
Bergmans, W. and J.E. Hill, 1980. On a new species of Rousettus Gray, 1821, from Sumatra and Borneo (Mammalia: Megachiroptera). Bull. Brit. Museum Natural History, 38: 95-104.

Bergmans, W., 1994. Taxonomy and biogeography of African fruit bats (Mammalia, Megachiroptera). 4. The genus Rousettus Gray, 1821. Beaufortia, 44: 79-126.

Bergmans, W., 1997. Taxonomy and biogeography of African fruit bats (Mammalia, Megachiroptera). 5. Genera Lissonycteris Andersen, 1912, Myonicteris Matschie, 1899 and Megaloglossus, Pagentecher 1885; general remarks and conclusions; annex: Key to all species. Beaufortia, 47: 11-90.

Rookmaker, L.C. and W. Bergmans, 1981. Taxonomy and geography of Rousettus amplexicaudatus (Geoffroy, 1810) with comparative notes on sympatric congeners (Mammalia, Megachiroptera). Beaufortia, 31: 1-29.

Bush Warriors, 2013. "IUCN Species of the Day: Madagascan rousette" (On-line).

Corbet, G.B. and J.E. Hill, 1992. The Mammals of the Indomalayan Region: A Systematic Review. 1st Edn., Oxford University Press, London, ISBN-10: 0198546939, pp: 488.

Desmarest, A.G., 1820. Mammalogie ou description des especès de mammifères: i-viii, 1-555, i (Veuve Agasse, Paris).

Saint-Hilaire, G., 1810. Description des rousettes et des céphalotes, deux nouveaux genres de la famille des chauve-souris. Annls. Mns. Hist. Nat. Paris, 15: 86-108.

Grzimek, B., 2003. Grzimek's Animal Life Encyclopedia: Mammals. In: Order: Rodentia, Schlager, N., D. Olendorf, M. McDade (Eds.), Gale Group, Farmington Hills, pp: 126-128.

Jenkins, R. and P. Racey, 2008. Bats as bushmeat in Madagascar. Madagascar Conservation and Development, 3/1: 22-30.

Jentink, F.A., 1879. On a new genus and species of bat from Celebes. Notes Leyden Mus. 1:117-119.
Koopman, K., 1993. Order Chiroptera. In: Mammals Species of the World, Wilson, D.E. and D.M. Reeder (Eds.), Smithsonian Institution Press, Washington, pp: 137-241.

Kwiecinski, G. and T. Griffiths, 1999. Rousettus egyptiacus. Mammalian Species, 611: 1-9.

Lee, R.J., J. Riley and R. Merrill, 2001. Biodiversity and Conservation in Northern part of Sulawesi. WCS-IP and NRM, Prima Centra, Jakarta.

Lengkong, H.J., 2009. Bat diversity in tangkokoduasudara sanctuary based on position above sea level. J. Ilmiah Sains, 9: 218-229.

Maryanto, I. and M. Yani, 2003. A new species of Rousettus (Chiroptera: Pteropodidae) from Lore Lindu, Central Sulawesi. Mammal Study, 28: 111-120. DOI: $10.3106 /$ mammalstudy.28.111

McNab, B., 1969. The economics of temperature regulation in Neotropical bats. Comparative Biochem. Physiol., 31: 227-268.

Medellín, R.A., M. Equihua and M.A. Amin, 2000. Bat diversity and abundance as indicators of disturbance in neotropical rainforests. Conserv. Biol., 14: 1666-1675. DOI: $10.1111 /$ j.1523-1739.2000.99068.x

Payne, J and C. Francis, 1985. "IUCN Species of the Day: Madagascan rousette.

Payne, J., C.M. Francis, K. Phillipps and S.N. Kartikasari, 2000. Mamalia di Kalimantan, Sabah, Sarawak and Brunei Darussalam. 1st Edn., The Sabah Society Malaysia and Wildlife Conservation Society Indonesia Program, pp: 386.

Suyanto, A., 2001. Bats of Indonesia. Biological Research and Development Center- LIPI Bogor, Indonesia.

Suyanto, A., M. Yoneda, I. Maryanto, J. Maharadatunkamsi and Sugarjito, 2002. Checklist of Mammals of Indonesia: Scientific Names and Distribution Area Tables in Indonesia Including CITES, IUCN and Indonesian Categories for Conservation. 1st Edn., LIPI-JICA-PHKA, Bogor, pp: 10.

\section{Supp. Data}

Table 1. Skull and external body characters of genus Rousettusbats a. Skull characters

\begin{tabular}{|c|c|c|c|c|c|c|c|c|c|c|c|c|c|c|c|c|c|c|c|}
\hline Species & & GSL & ZB & LIW & POW & BCW & BL & MSF & PL & CBL & CCL & $\mathbf{C}^{1} \mathbf{M}^{3}$ & $\mathrm{C}^{1} \mathrm{C}^{1}$ & $\mathbf{M}^{3} \mathbf{M}^{3}$ & DL & RAP & $\mathbf{C}_{1} \mathbf{M}_{3}$ & $\mathrm{C}_{1} \mathrm{C}_{1}$ & $\mathbf{M}_{3} \mathbf{M}_{3}$ \\
\hline \multirow[t]{5}{*}{ R. amplexicaudatus } & $\mathrm{N}$ & 10 & 10 & 10 & 10 & 10 & 10 & 10 & 10 & 10 & 10 & 10 & 10 & 10 & 10 & 10 & 10 & 10 & 10 \\
\hline & Min & 34.60 & 20.30 & 6.90 & 6.40 & 13.90 & 2.60 & 4.00 & 15.10 & 33.10 & 31.40 & 11.10 & 4.60 & 8.70 & 26.50 & 10.50 & 12.80 & 3.00 & 8.10 \\
\hline & Max & 37.40 & 23.90 & 8.00 & 9.80 & 15.40 & 4.20 & 5.70 & 19.70 & 37.10 & 35.00 & 13.90 & 7.30 & 11.00 & 29.40 & 12.90 & 16.00 & 5.10 & 10.30 \\
\hline & $\mathrm{X}$ & 36.14 & 21.85 & 7.49 & 7.39 & 14.42 & 3.63 & 4.79 & 17.54 & 34.63 & 32.99 & 12.49 & 6.40 & 9.57 & 27.58 & 11.62 & 13.97 & 3.88 & 9.10 \\
\hline & SD & 1.09 & 1.11 & 0.37 & 0.96 & 0.43 & 0.55 & 0.48 & 1.34 & 1.26 & 1.23 & 0.96 & 0.82 & 0.81 & 0.96 & 0.74 & 0.91 & 0.60 & 0.83 \\
\hline \multirow[t]{5}{*}{ R. celebensis } & $\mathrm{N}$ & 10 & 10 & 10 & 10 & 10 & 10 & 10 & 10 & 10 & 10 & 10 & 10 & 10 & 10 & 10 & 10 & 10 & 10 \\
\hline & Min & 35.50 & 19.60 & 6.40 & 6.80 & 13.90 & 2.60 & 4.50 & 16.50 & 32.20 & 30.10 & 12.00 & 6.10 & 8.80 & 25.20 & 10.10 & 13.50 & 3.30 & 8.00 \\
\hline & Max & 39.30 & 23.50 & 7.90 & 9.60 & 15.00 & 3.85 & 5.50 & 19.10 & 37.40 & 34.70 & 13.80 & 7.60 & 9.60 & 29.60 & 12.70 & 15.30 & 4.80 & 9.40 \\
\hline & $\mathrm{X}$ & 37.30 & 22.20 & 7.27 & 8.01 & 14.48 & 3.17 & 5.07 & 17.99 & 35.41 & 33.44 & 13.10 & 6.74 & 9.27 & 27.67 & 11.40 & 14.17 & 4.09 & 8.89 \\
\hline & SD & 1.75 & 1.21 & 0.48 & 0.76 & 0.33 & 0.52 & 0.31 & 0.86 & 1.43 & 1.30 & 0.52 & 0.50 & 0.27 & 1.31 & 0.80 & 0.61 & 0.51 & 0.49 \\
\hline R. tangkokoensis & $\mathrm{N}$ & 9 & 9 & 9 & 9 & 9 & 9 & 9 & 9 & 9 & 9 & 9 & 9 & 9 & 9 & 9 & 9 & 9 n. sp. & 9 \\
\hline \multirow[t]{4}{*}{ n. sp. } & Min & 30.30 & 18.00 & 6.70 & 8.60 & 13.70 & 2.40 & 4.10 & 14.60 & 28.00 & 27.50 & 9.30 & 5.50 & 8.80 & 23.00 & 9.50 & 10.10 & 3.50 & 8.20 \\
\hline & Max & 37.80 & 24.40 & 8.30 & 9.70 & 14.70 & 2.80 & 5.00 & 17.60 & 36.50 & 34.90 & 12.60 & 7.30 & 9.80 & 28.30 & 11.80 & 14.90 & 4.20 & 9.50 \\
\hline & $\mathrm{X}$ & 34.67 & 20.79 & 7.18 & 8.99 & 14.15 & 2.60 & 4.54 & 16.34 & 33.11 & 31.84 & 11.27 & 6.12 & 9.13 & 25.72 & 10.38 & 12.33 & 3.79 & 8.84 \\
\hline & SD & 2.74 & 2.17 & 0.52 & 0.39 & 0.33 & 0.16 & 0.30 & 1.00 & 3.14 & 2.50 & 1.26 & 0.58 & 0.33 & 1.79 & 0.76 & 1.64 & 0.24 & 0.37 \\
\hline
\end{tabular}


Hanry Jefry Lengkong et al. / OnLine Journal of Biological Sciences 2016, 16 (2): 90.101 DOI: 10.3844/ojbsci.2016.90.101

1b. External body characters

\begin{tabular}{|c|c|c|c|c|c|c|c|c|}
\hline Species & & SV & FL & FA & TIB & $\mathrm{HF}$ & EAR & TAIL \\
\hline \multirow[t]{5}{*}{ R. amplexicaudatus } & $\mathrm{N}$ & 224.00 & 224.00 & 224.00 & 224.00 & 224.00 & 224.00 & 224.00 \\
\hline & Min & 70.00 & 18.80 & 71.00 & 23.50 & 16.00 & 13.30 & 8.70 \\
\hline & Max & 95.40 & 41.30 & 81.00 & 42.00 & 30.30 & 33.40 & 39.00 \\
\hline & $\mathrm{X}$ & 83.62 & 36.55 & 74.87 & 34.43 & 22.30 & 17.22 & 28.11 \\
\hline & SD & 5.08 & 2.24 & 2.13 & 1.65 & 2.09 & 1.63 & 4.03 \\
\hline \multirow[t]{5}{*}{ R. celebensis } & $\mathrm{N}$ & 219.00 & 219.00 & 219.00 & 219.00 & 219.00 & 219.00 & 219.00 \\
\hline & Min & 60.60 & 30.50 & 67.00 & 25.90 & 13.50 & 10.70 & 16.60 \\
\hline & Max & 97.00 & 44.30 & 81.00 & 37.30 & 26.60 & 26.30 & 33.80 \\
\hline & $X$ & 78.41 & 36.23 & 73.25 & 33.64 & 20.62 & 16.76 & 26.09 \\
\hline & SD & 7.17 & 2.10 & 2.29 & 1.83 & 2.07 & 1.67 & 3.12 \\
\hline \multirow{5}{*}{ R. tangkokoensis n. sp. } & $\mathrm{N}$ & 9.00 & 9.00 & 9.00 & 9.00 & 9.00 & 9.00 & 9.00 \\
\hline & Min & 65.50 & 31.30 & 72.00 & 29.30 & 20.70 & 15.10 & 16.70 \\
\hline & Max & 91.90 & 38.80 & 86.00 & 38.30 & 23.60 & 20.10 & 25.90 \\
\hline & $\mathrm{X}$ & 80.87 & 35.71 & 79.00 & 34.30 & 22.33 & 18.07 & 21.30 \\
\hline & SD & 8.94 & 2.72 & 5.77 & 3.60 & 1.11 & 1.47 & 3.26 \\
\hline
\end{tabular}

